\title{
PENGARUH KEPEMIMPINAN TRANSFORMASIONAL DAN KOMITMEN ORGANISASIONAL TERHADAP ORGANIZATIONAL CITIZENSHIP BEHAVIOR DI VILLA KUBU MANGGALA SEMINYAK
}

\author{
Made Satwika Dwi Cahyadi ${ }^{1}$ \\ I Gusti Bagus Honor Satrya ${ }^{2}$ \\ ${ }^{1,2}$ Fakultas Ekonomi dan Bisnis Universitas Udayana (Unud), Bali, Indonesia \\ e-mail: satwikacahyadi08@gmail.com
}

\begin{abstract}
ABSTRAK
Salah satu faktor yang harus diperhatikan dalam mengelola sumber daya manusia adalah rasa suka rela karyawan dalam membantu rekan kerja diluar tugas tanggung jawabnya (Organizational Citizenship Behavior). Gejala-gejala permasalahan yang berkaitan dengan rendahnya OCB disebabkan karena rendahnya kepemimpinan transformasional dan komitmen organisasional. Tujuan dari penelitian ini adalah untuk mengetahui pengaruh dari kepemimpinan transformasional dan komitmen organisasional terhadap OCB di Villa Kubu Manggala Seminyak. Penelitian ini dilakukan di Villa Kubu Manggala Seminyak dengan menggunakan metode sensus yaitu sebanyak 30 responden. Pengumpulan data dilakukan dengan penyebaran kuisioner dengan menggunakan skala likert 5 point untuk mengukur 12 item pernyataan. Pengujian yang dilakukan menggunakan uji asumsi klasik yaitu uji normalitas, uji multikolinearitas, uji heteroskedastisitas, uji f serta uji t. Hasil analisis menunjukkan bahwa kepemimpinan transformasional berpengaruh positif dan signifikan terhadap OCB dan komitmen organisasional berpengaruh positif dan signifikan terhadap OCB. Untuk meningkatkan prilaku OCB di dalam organisasi sebaiknya perusahaan lebih memperhatikan komitmen normatif dan kesempatan promosi.
\end{abstract}

Kata Kunci: Kepemimpinan Transformasional, Komitmen Organisasi, dan Organizational Citizenship Behavior.

\begin{abstract}
One of the factors that must be considered in managing human resources is the volunteerism of employees in helping co-workers outside of their responsibilities (Organizational Citizenship Behavior). The symptoms of problems associated with low $O C B$ are due to the low transformational leadership and organizational commitment. The purpose of this study was to determine the effect of transformational leadership and organizational commitment to OCB at Villa Kubu Manggala Seminyak. This research was conducted at Villa Kubu Manggala Seminyak by using census method that is 30 respondents. The data was collected by distributing questionnaires using a 5-point likert scale to measure 12 statement items. Tests conducted using the classical assumption test that is normality test, multicollinearity test, heteroscedasticity test, $f$ test and $t$ test. The results of the analysis show that transformational leadership has a positive and significant effect on $O C B$ and organizational commitment has a positive and significant impact on $O C B$. To improve the OCB's behavior within the organization, companies should pay more attention to normative commitment and promotion opportunities.
\end{abstract}

Keywords: Transformational Leadership, Organizational Commitment, and Organizational Citizenship Behavior. 


\section{PENDAHULUAN}

Perkembangan dunia usaha di bidang jasa pariwisata seperti hotel, homestay dan villa khususnya yang berada di Bali. Dewasa ini dirasakan semakin maju dan pesat yang membawa dampak persaingan yang semakin tajam (Supiatni, 2012). Setiap perusahaan dalam menjalankan usahanya tidak dapat melepas perhatian pada pengelolaan sumber daya manusia. Masalah sumber daya manusia merupakan hal yang sangat menentukan keberhasilan suatu perusahaan dalam mencapai tujuan yang telah ditetapkan, di mana tujuan tersebut tidak akan tercapai bila karyawan tidak melaksanakan pekerjaan dengan baik (Sylvia, 2014).

Keberhasilan dan kesuksesan perusahaan sangat ditentukan dari bagaimana perusahaan mengelola sumber daya yang dimilikinya. Simamora (2004:4) menyatakan bahwa aset organisasi paling penting yang harus dimiliki oleh perusahaan dan sangat diperhatikan oleh manajemen adalah aset manusia dari organisasi tersebut. Hal ini disebabkan karena sumber daya manusia merupakan penggerak utama perusahaan dengan mengelola dan mengembangkan perusahaan agar mencapai tujuan. Walaupun aspek teknologi yang modern, apabila tidak diimbangi dengan sumber daya manusia yang baik atau memadai, maka sulit terjadinya hasil kerja yang baik di dalam perusahaan tersebut. Tanpa adanya sumber daya manusia, aktivitas perusahaan tidak akan terjadi (Hasibuan, 2008:12). Setiap perusahaan akan berupaya dan berorientasi pada tujuan jangka panjang yaitu berkembangnya perusahaan yang sejalan pula dengan meningkatnya kesejahteraan para karyawannya. 
Made Satwika Dwi Cahyadi, Pengaruh Kepemimpinan Transform...

Davoudi (2010) menyebutkan bahwa dalam setiap perusahaan sumber daya manusia merupakan sumber daya paling vital yang dimiliki oleh perusahaan. Dalam menjalankan sejumlah tugas dalam organisasi dan untuk dapat bersaing dengan kompetitor, sumber daya manusia tidak cukup hanya melakukan tugasnya masing-masing sesuai dengan job description (uraian tugas) saja, namun mereka harus memiliki perilaku extra-role (peran ektra) yang dapat memberi pengaruh positif bagi produktivitas organisasi. Perdana (2010) menjelaskan bahwa salah satu perilaku yang dapat meningkatkan produktivitas karyawan di dalam organisasi yaitu perilaku extra-role atau disebut juga perilaku Organizational Citizenship Behavior (OCB).

OCB merupakan bentuk kegiatan sukarela dari anggota organisasi yang mendukung fungsi organisasi sehingga perilaku ini diekspresikan dalam bentuk tindakan-tindakan yang menunjukkan sikap tidak mementingkan diri sendiri dan perhatian pada kesejahteraan orang lain. Dalam melakukan suatu tugas atau pekerjaan, seseorang karyawan memang tidak selalu digerakkan perusahaan dan pimpinan melainkan menguntungkan dirinya sendiri, dimana karyawan memerlukan kemampuan berempati dalam pekerjaan yang dilakukan, seseorang karyawan bisa memahami orang lain di lingkungan tempat mereka bekerja agar menyelaraskan nilai-nilai individual yang dianutnya dengan nilai-nilai yang dianut lingkungannya, sehingga muncul perilaku yang "nice” (bagus) yaitu sebagai "good citizen" (warga Negara yang baik) (Hardaningtyas, 2004).

Dalam suatu perusahaan membutuhkan karyawan yang memperlihatkan perilakunya seperti membantu rekan kerjanya baik kelompok maupun tim kerja, 
mengajukan diri untuk pekerjaan ekstra, menghindari konflik dalam perusahaan, mempunyai semangat tinggi dan mentaati peraturan yang ada dalam perusahaan. Saptoani (2011) mengemukakan organisasi yang berhasil adalah organisasi yang memiliki karyawan yang bekerja melebihi tanggung jawab tugasnya dan secara sukarela memberikan waktu dan tenaganya untuk kesuksesan pelaksanaan tugas.

Penelitian ini berupaya untuk memperluas pemahaman mengenai pengaruh OCB di Villa Kubu Manggala Seminyak. OCB sebagai perilaku individual yang discretionary (bersifat bebas), yang tidak secara langsung dan eksplisit mendapat penghargaan dari sistem imbalan formal, dan yang secara keseluruhan (agregat) meningkatkan efisiensi dan efektivitas fungsi-fungsi organisasi, bersifat bebas dan sukarela karena perilaku tersebut tidak diharuskan oleh persyaratan peran atau deskripsi jabatan yang secara jelas dituntut berdasarkan kontrak dengan organisasi, melainkan sebagai pilihan personal (Organ, 2006).

Villa Kubu Manggala adalah perusahaan yang bergerak di bidang jasa pariwisata khususnya dalam penyewaan villa untuk wisatawan domestik maupun mancanegara. Sebagai salah salah satu perusahaan yang bergerak di bidang jasa pariwisata Villa Kubu Manggala berorientasi mengatur, menjaga dan mengawasi segala kegiatan yang ada dalam perushaan agar dapat dipastikan sangat memerlukan karyawan yang memiliki peran ekstra di luar pekerjaannya, sehingga dapat bekerja lebih efektif dan tepat waktu dalam mencapai tujuan perusahaan sedangkan di Villa Kubu Manggala belum sepenuhnya menerapkan OCB yang dikarenakan para karyawan di Villa Kubu Manggala tidak memiliki rasa empati kepada karyawan satu dengan karyawan yang lainnya 
Made Satwika Dwi Cahyadi, Pengaruh Kepemimpinan Transform...

Faktor yang mempengaruhi munculnya OCB adalah disposisi dan motif individu, kohesivitas kelompok, sikap pegawai dimana didalamnya termasuk adalah komitmen organisasi dan gaya kepemimpinan transformasional (Shweta, $\mathrm{j}$, dan Srirang, j. 2010). Rahmi (2013) menyatakan pada setiap organisasi guna memaksimalkan perilaku OCB karyawan, maka diperlukan keefektifan peran pemimpin yang bersangkutan. Peranan pemimpin sangat diperlukan dalam perusahaan untuk mendorong karyawan dalam meningkatkan kemampuan di dalam pekerjaanya. Kepemimpinan adalah cara seseorang pemimpin mempengaruhi perilaku bawahan, agar mau bekerja sama dan bekerja secara produktif untuk mencapai tujuan organisasi (Hasibuan, 2008:170). Seorang pemimpin memiliki banyak pilihan gaya kepemimpinan yang digunakannya dalam mempengaruhi bawahannya agar mau bekerja sama untuk tujuan organisasi.

Gaya kepemimpinan adalah norma perilaku yang digunakan oleh seseorang pemimpin untuk mencoba mempengaruhi perilaku orang lain atau bawahannya (Thoha, 2010;49). Gaya kepemimpinan yang biasanya diterapkan oleh perusahaan adalah kepemimpinan transformasional. Kepemimpinan transformasional merupakan suatu perikalu pemimpin yang menyediakan perhatian individu, rangsangan intelektual serta lebih menyerukan nilai moral dari para bawahan atau pengikut untuk meningkatkan kesadaran (Rorimpandey, 2013).

Bass dan Riggio (2006:123) mengemukakan bahwa pemimpin yang memiliki gaya kepemimpinan transformasional akan bisa menstimulasi dan menginspirasi para pengikutnya untuk bisa meraih hasil yang lebih baik untuk 
meningkatkan kemajuan dari perusahaan. Kepemimpinan transformasional merupakan sebuah proses dimana di dalamnya orang-orang mengalami perubahan baik emosi, nilai, etika, standar, maupun tujuan hidup mereka.

Saeed dan Ahmad (2012), menyatakan bahwa dengan mengadopsi gaya kepemimpinan transformasional untuk mempengaruhi bawahannya sehingga mereka dapat terlibat dalam perilaku ekstra peran, sehingga OCB bermanfaat bagi pertumbuhan organisasi. Cho dan Dansereau (2010) menemukan bahwa adanya korelasi positif antara kepemimpinan transformasional dengan OCB. Penelitian yang diakukan oleh Ismail et al., (2011) menunjukan bahwa kemampuan pemimpin dalam menunjukan gaya transformasional dalam melaksanakan fungsifungsi organisasi memiliki dampak yang signifikan terhadap hasil kerja serta komitmen organisasional. Oleh karena itu, kepemimpinan transformasional merupakan faktor yang bisa mempengaruhi tingkat komitmen organisasional dan pada akhirnya meningkatkan toleransi pada karyawan, sehingga peran OCB pada karyawan akan tercipta.

Komitmen organisasional adalah sikap loyalitas karyawan dan proses berkelanjutan dari seorang anggota organisasi mengekspresikan perhatian mereka kepada kesuksesan dan kebaikan organisasinya (Luthans, 2006:249). Sikap ini membentuk seseorang untuk berperilaku positif, untuk menjadi disiplin dalam bekerja, untuk mematuhi aturan dan kebijakan perusahaan, untuk menjaga hubungan baik dengan rekan kerja dan meningkatkan tingkat pencapaian seseorang. Karyawan yang tidak disiplin, tidak mematuhi aturan dan kebijakan perusahaan memiliki komitmen yang rendah terhadap perusahaan sedangkan 
Made Satwika Dwi Cahyadi, Pengaruh Kepemimpinan Transform...

komitmen organisasional yang tinggi sangat diperlukan oleh sebuah perusahaan (Ngadiman et al. 2013). Komitmen organisasional mengindikasikan bagaimana seorang individu mengindentifikasikan dirinya sendiri dengan organisasi dan bagaimana inidividu tersebut terikat dengan tujuan-tujuan dari organisasi dan memiliki keinginan untuk melakukan hal lebih untuk organisasi. Komitmen dalam organisasi akan membuat pekerja memberikan yang terbaik kepada organisasi dimana ia bekerja. Bekerja dengan komitmen yang tinggi akan memiliki komitmen terhadap organisasi yang tinggi dan akan cenderung senang membantu serta bekerja sama.

Berdasarkan hasil dari pra-research (pengamatan awal) terhadap 10 orang responden dari total 30 orang karyawan di Villa Kubu Manggala Seminyak, menunjukan adanya indikasi rendahnya perilaku OCB yang diikuti dengan kepemimpinan transformasional dan komitmen organisasional yang juga masih rendah. Indikasi yang menunjukan rendahnya prilaku OCB pada karyawan yaitu masih kurangnya niat dari dalam diri karyawan untuk membantu rekan kerja yang memiliki beban kerja lebih banyak saat karyawan tersebut telah selesai mengerjakan tugasnya. Ini terjadi hampir di setiap bagian yang ada di dalam perusahaan menyatakan kurangnya niat membantu rekan kerja karena setiap karyawan merasa sudah memiliki tugas tersendiri yang diberikan oleh perusahaan. Pada kondisi ideal, karyawan sepatutnya memiliki peran OCB dengan menunjukan perilaku sukarela untuk mau melakukan tugas atau bekerja diluar tanggung jawab dan kewajibannya demi tercapainya tujuan organisasi oleh karena 
itu, untuk meningkatkan OCB perlu adanya faktor-faktor yang mempengaruhinya antara lain kepemimpinan transformasional dan komitmen organisasional.

Rendahnya kepemimpinan transformasional dapat di lihat dari hasil wawancara yang dilakukan dengan 10 orang karyawan yang menyatakan masih kurangnya inovasi yang dilakukan oleh pemimpin perusahaan yang menyebabkan potensi perusahaan menurun sehingga perusahaan sulit untuk bersaing dibidang usaha jasa pariwisata, dan karyawan merasa pimpinan kurang berpartisipasi dengan baik, sehingga karyawan kurang mematuhi koordinasi yang telah diberikan.

Rendahnya komitmen organisasional terlihat dari sikap anggota masingmasing bagian yang ada di dalam peruashaan yang menunjukan kurangnya rasa kekeluargaan dan sikap yang cenderung tidak ingin terlibat langsung dalam setiap program yang bertujuan untuk mencapai tujuan dan memajukan organisasi.

OCB merupakan bagian dari ilmu perilaku organisasi, OCB merupakan bentuk perilaku kerja yang biasanya tidak terlihat atau diperhitungkan, terdapat dua pendekatan terhadap konsep OCB yaitu OCB merupakan kinerja extra role (peran ektra) yang terpisah dari kinerja in-role (sesuai peran) atau kinerja yang sesuai deskripsi kerja, pendekatan kedua adalah memandang OCB dari prinsip atau filosofi politik, pendekatan ini mengidentifikasi perilaku anggota organisasi dengan perilaku kewarganegaraan, perilaku ini muncul karena perasaan individu sebagai anggota organisasi yang memiliki rasa puas apabila dapat melakukan sesuatu yang lebih dari organisasi Wulani (2005). 
Aldag dan Rescke (dalam Rini 2007) perilaku ekstra peran diartikan sebagai kontribusi seorang individu dalam bekerja, perbedaan mendasar antara perilaku in role (sesuai peran) dengan extra role (peran ektra) adalah pada reward (penghargaan), pada in role (sesuai peran) biasanya dihubungkan dengan reward (penghargaan) dan sanksi (hukuman), sedangkan extra role (peran ektra) terbebas dari reward (penghargaan) dan perilaku yang dilakukan oleh individu tidak diorganisir dalam reward yang mereka terima. Dyne (dalam Chien, 2004) (OCB) merupakan istilah yang digunakan untuk mengidentifikasikan perilaku karyawan, OCB ini mengacu pada konstruk dari "extra-role (peran ektra) behavior (perilaku)" (ERB), didefinisikan sebagai perilaku yang menguntungkan organisasi dan atau berniat untuk menguntungkan organisasi, yang langsung dan mengarah pada peran pengharapan, dengan demikian OCB merupakan perilaku yang fungsional, extra-role (peran ektra), pro-sosial yang mengarahkan individu, kelompok dan atau organisasi.

Northouse (2013:175), menyatakan bahwa pendekatan baru yang kini sedang populer dan diminati oleh banyak peneliti adalah pendekatan transformasional. Kepemimpinan transformasional merupakan sebuah proses dimana didalamnya orang-orang mengalami perubahan baik emosi, nilai, etika, standar, maupun tujuan mereka. Kepemimpinan transformasional memiliki kekuatan untuk mempengaruhi pengikutnya, baik dalam cakupan yang kecil seperti mempengaruhi satu pengikut hingga cakupan yang luas sehingga dapat mempengaruhi seluruh organisasi bahkan seluruh budaya. Surbakti (2013), menjelaskan bahwa interkasi yang dimiliki antara pemimpin yang memiliki gaya 
kepemimpinan transformasional dengan bawahannya ditandai dengan besar atau kecilnya pengaruh yang diberikan oleh pemimpin terhadap bawahannya untuk berubah.

Luthans (2006:249) menyatakan bahwa komitmen organisasional merupakan sikap yang menunjukan loyalitas karyawan dan merupakan proses berkelanjutan bagaimana seorang anggota organisasi mengekspresikan perhatian mereka kepada kesuksesan dan kebaikan organisasinya. Lebih lanjut sikap loyalitas ini diindikasikan dengan tiga hal, yaitu: (1) keinginan kuat seseorang untuk tetap menjadi anggota organisasinya; (2) kemauan untuk mengerahkan usahanya untuk organisasinya; (3) keyakinan dan penerimaan yang kuat terhadap nilai-nilai dan tujuan organisasinya. Komitmen organisasional akan membuat pekerja memberikan yang terbaik kepada organisasi tempat dia bekerja. Pekerja yang memiliki komitmen organisasional tinggi akan lebih berorientasi pada kerja, cenderung senang membantu dan dapat bekerjasama.

Sejumlah penelitian telah dilakukan untuk menganalisi pengaruh variabel kepemimpinan transformasional terhadap variabel OCB. Hasil penelitian Amber Humphrey (2012) melakukan penelitian pada 128 karyawan swasta di Kansas menunjukan bahwa kepemimpinan transformasional berpengaruh positif terhadap OCB. Humphrey (2012) mengatakan bahwa hubungan positif ini disebabkan karena dipandangannya pemimpin sebagai panutan, adanya kepercayaan, motivasi, perhatian terhadap kebutuhan karyawan sehingga dengan demikian karyawan memiliki kecenderungan untuk melaksanakan perilaku ekstra peran (OCB). Penelitian yang dilakukan oleh Lian dan Tui (2012) menunjukan bahwa 
Made Satwika Dwi Cahyadi, Pengaruh Kepemimpinan Transform...

gaya kepemimpinan transformasional memiliki hubungan positif yang signifikan terhadap OCB bawahan.

Hasil penelitian Lee et al. (2013) membuktikan bahwa kepemimpinan transformasional memiliki pengaruh positif dan signifikan terhadap OCB. Hal ini ditunjukan dari semakin seringnya pemimpin mendorong karyawan untuk mencapai tujuan organisasi dan semakin banyak karyawan merasa percaya diri atas kemampuan mereka untuk melaksanakan tugas dan hal ini secara tidak langsung mempengaruhi karyawan untuk rela melakukan OCB. Penelitian Maptuhah Rahmi (2013) pada 125 guru tetap SMA Negeri di Kabupaten Lombok Timur mengungkapkan bahwa kepemimpinan transformasional berpengaruh positif dan signifikan terhadap OCB. Apabila intensitas penerapan kepemimpinan transformasional tinggi, maka tingkat OCB akan meningkat (Rahmi, 2013). Lamidi (2008) melakukan penelitian pada 42 dosen di Surakarta mengungkapkan bahwa kepemimpinan transformasional memiliki pengaruh positif terhadap OCB, dimana semakin tinggi persepsi yang dimiliki bawahan terhadap atasannya, maka OCB akan semakin tinggi. Berdasarkan latar belakang dan pokok permasalahan yang telah diuraikan, maka dapat dikemukakan hipotesis sebagai berikut:

$\mathrm{H}_{1}$ : Kepemimpinan transformasional berpengaruh positif dan signifikan terhadap OCB.

Sejumlah penelitian telah dilakukan untuk menganalisi pengaruh variabel komitmen organisasional terhadap variabel OCB. Hasil penelitian Suparta, dkk (2013) menyatakan komitmen organisasional berpengaruh positif dan signifikan terhadap OCB, artinya setiap peningkatan komitmen organisasional akan 
berakibat pada peningkatan OCB. Penelitian yang dilaksanakan oleh Bakan et al. (2013) menemukan bahwa ada hubungan yang signifikan antara komitmen organisasional dan OCB di kalangan perempuan pekerja di sektor tekstil Kahramanmaras, Turki.

Hasil penelitian Merry (2013) yang menyatakan bahwa komitmen organisasional mempunyai pengaruh positif dan signifikan terhadap OCB karyawan di Rumah Sakit Bhayangkara trijata Denpasar. Penelitian yang dilaksanakan oleh Anshori (2013) menemukan bahwa adanya hubungan antara komitmen organisasional dengan OCB. Berdasarkan analisis koefisien korelasi regresi antara komitmen organisasional dengan OCB menunjukan adanya hubungan positif yang signifikan. Artinya semakin tinggi nilai komitmen organisasional seorang karyawan maka semakin tinggi pula nilai OCB karyawan tersebut. Rehan et al. (2013) mengungkapkan bahwa keseluruhan bentuk komitmen mempengaruhi OCB secara signifikan. Berdasarkan latar belakang dan pokok permasalahan yang telah diuraikan, maka dapat dikemukakan hipotesis sebagai berikut:

$\mathrm{H}_{2}$ : Komitmen organisasional berpengaruh positif dan signifikan terhadap OCB.

Sugiyono (2011:60) mengungkapkan bahwa kerangka berfikir merupakan model konseptual tentang bagaimana teori berhubungan dengan berbagai faktor yang telah diidentifikasi sebagai hal yang penting jadi dengan demikian maka kerangka berfikir adalah sebuah pemahaman yang melandasi pemahamanpemahaman lainnya, sebuah pemahaman yang paling mendasar dan menjadi 
Made Satwika Dwi Cahyadi, Pengaruh Kepemimpinan Transform...

pondasi bagi setiap pemikiran atau suatu bentuk proses dari keseluruhan penelitian yang akan dilakukan.

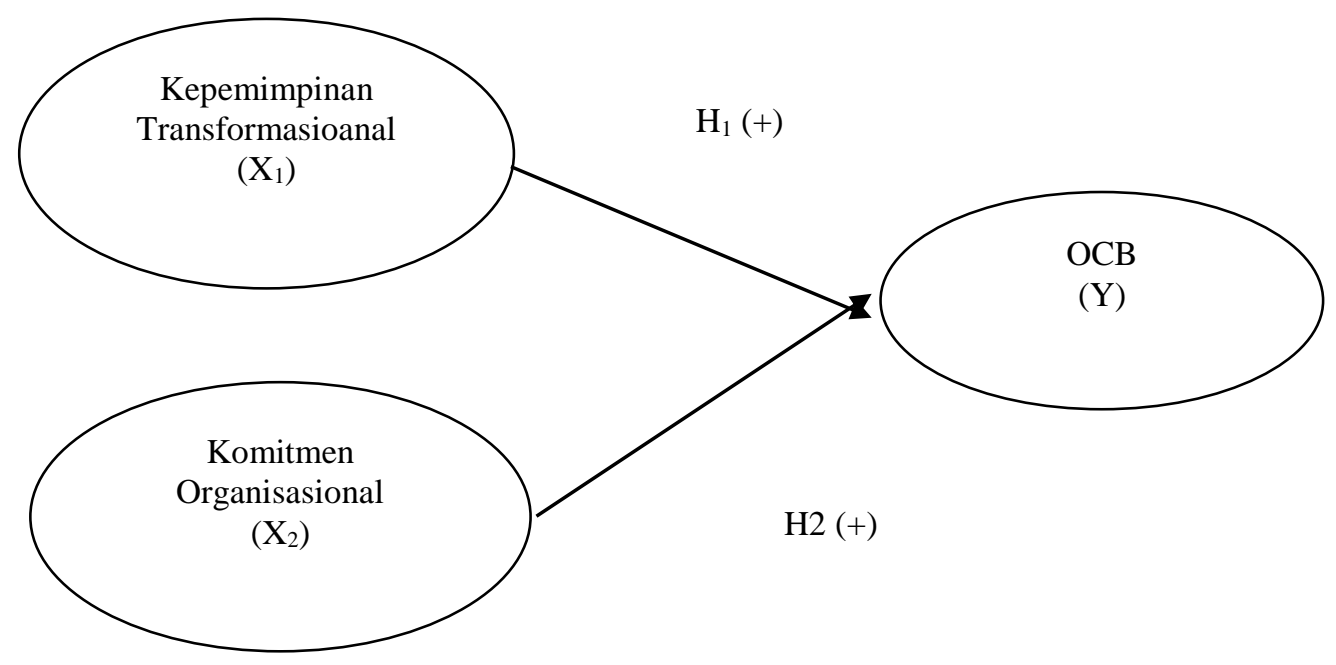

Gambar 1. Kerangka Konseptual Penelitian Sumber : data diolah, 2017

\section{METODE PENELITIAN}

Berdasarkan permasalahan yang di teliti, Penelitian ini termasuk dalam penelitian yang bersifat asosiatif,yaitu penelitian yang bertujuan untuk mengetahui hubungan dari dua variabel atau lebih (Sugiyono, 2009:5). Lokasi penelitian dilakukan di Villa Kubu Manggala Seminyak dengan lokasi di Jalan Yasa Bali Sujati Kerobokan Kelod. Tempat ini dipilih sebagai lokasi penelitian karena berdasarkan hasil wawancara yang telah dilakukan dengan 10 orang karyawan ditemukan adanya masalah yang berkaitan dengan OCB di Villa Kubu Manggala Seminyak.

Objek dari penelitian ini adalah Kepemimpinan Transformasional, Komitmen Organisasional dan OCB di Villa Kubu Manggala Seminyak. Variabel 
yang diteliti dalam penelitian ini adalah kepemimpinan transformasional $\left(\mathrm{X}_{1}\right)$ dan komitmen organisasional $\left(\mathrm{X}_{2}\right)$ sebagai variabel bebas, serta OCB (Y) sebagai variabel terikat. Kepemimpinan Transformasional adalah pemimpin yang mendorong karyawannya untuk memunculkan ide-ide baru dan solusi kreatif atas masalah-masalah yang dihadapi.

Komitmen Organisasional merupakan konstruk psikologis atau keinginan yang dimiliki oleh anggota untuk tetap bertahan dalam organisasi karena mereka ingin (afektif), mereka perlu (kelanjutan), mereka harus melakukan (normatif) serta berusaha dengan keras untuk mewujudkan tujuan dari organisasi tersebut. OCB merupakan perilaku sukarela bekerja di luar tugas yang diberikan perusahaan atau di luar job description tanpa mengharapkan hadiah atau imbalan dikemudian hari.

Penelitian ini menggunakan dua jenis data yaitu data kuantitatif dan data kualitatif. Data kuantitatif adalah data yang berupa angka-angka atau data yang dapat diangkakan dengan cara memberi skor. Data kuantitatif dari penelitian ini adalah 30 orang karyawan di Villa Kubu Manggala Seminyak. data kualitatif adalah data yang berupa kata, kalimat, dan gambar yang berupa penjelasanpenjelasan. Data kualitatif dalam penelitian ini yaitu berupa struktur dan sejarah singkat di Villa Kubu Manggala Seminyak.

Penelitian ini juga menggunakan dua jenis sumber data yaitu sumber primer dan sekunder. Sumber primer adalah data yang diperoleh secara langsung dari responden penelitian, seperti data yang didapatkan berupa jawaban responden melalui wawancara dan kuisioner. Sumber sekunder adalah data yang diperoleh 
Made Satwika Dwi Cahyadi, Pengaruh Kepemimpinan Transform...

dalam bentuk sudah jadi, dikumpulkan dan diolah oleh perusahaan, seperti sejarah singkat perusahaan, data tentang jumlah karyawan serta dokumen-dokumen lain yang berkaitan dengan penulisan proposal penelitian ini.

Populasi dalam penelitian ini adalah seluruh karyawan di Villa Kubu Manggala Seminyak yang berjumlah 30 orang.

Tabel 1.

Populasi Karyawan

\begin{tabular}{clcc}
\hline No & & Jabatan & Jumlah \\
\hline 1 & Manajer & 1 \\
2 & Sekretaris & 1 \\
3 & Akutansi & 3 \\
4 & Kepala Pelayanan & 2 \\
5 & Makanan dan Minuman & 10 \\
6 & Operasional dan IT & 6 \\
7 & Sopir & 3 \\
8 & Keamanan & 4 \\
& Tota1 & 30 orang \\
\hline
\end{tabular}

Sumber: Villa Kubu Manggala Seminyak, 2016

Menurut Sugiyono (2013:116) sampel merupakan bagian dari jumlah dan karakteristik yang dimiliki oleh populasi tersebut. Sampel yang digunakan dalam penelitian ini adalah 30 responden. Metode yang digunakan dalam penelitian ini adalah metode penentuan sampling jenuh yaitu teknik penentuan sampel bila semua anggota populasi digunakan sebagai sampel.

Pengumpulan data dalam penelitian ini dilakukan dengan menggunakan metode wawancara dan kuisioner. Metode wawancara merupakan metode pengumpulan data yang dilakukan dengan tanya jawab langsung dengan beberapa karyawan untuk memperoleh keterangan mengenai masalah yang akan diteliti. Metode kuesioner merupakan metode pengumpulan data dengan menggunakan daftar pertanyaan yang disebarkan kepada karyawan untuk dimintai keterangan 
terhadap semua yang dialami dan berhubungan dengan masalah yang dibahas dalam penelitian ini.

Sebelum dilakukannya analisis regresi liniear berganda terlebih dahulu dilakukan uji validitas, uji realiabilitas dan uji asumsi klasik. Uji validitas merupakan derajat ketepatan antara data yang sesungguhnya terjadi pada objek peneliti dengan data yang dapat dilaporkan oleh peneliti. Uji Realiabilitas adalah alat untuk mengukur suatu kuisioner yang merupakan indikator variabel konstruk.Pengujian realiabilitas adalah berkaitan dengan masalah adanya kepercayaan terhadap instrumen penelitian. Uji asumsi klasik dilakukan dengan melakukan uji normalitas, uji multikolinearitas dan uji heteroskedastisitas.

Indikator variabel dalam penelitian ini seluruhnya diukur menggunakan Skala Likert Summated Ratings. Skala ini mengukur dimana subjek diminta untuk mengindikasikan tingkat setuju hingga tidak setuju yang dinyatakan oleh responden terhadap masing-masing pertanyaan.

Model analisis yang digunakan untuk menyelesaikan permasalahan penelitian ini adalah regresi linear berganda. Permasalahan yang harus dijawab adalah variabel bebas (kepemimpinan transformasional dan komitmen organisasional) berpengaruh secara simultan, parsial, dan dominan terhadap variabel terikat (OCB). Model regresi linier berganda dirumuskan sebagai berikut:

$\hat{\mathrm{Y}}=a+\beta_{1} X_{1}+\beta_{2} X_{2}+e$

Keterangan :

$\hat{\mathrm{Y}}=\mathrm{OCB}$ 


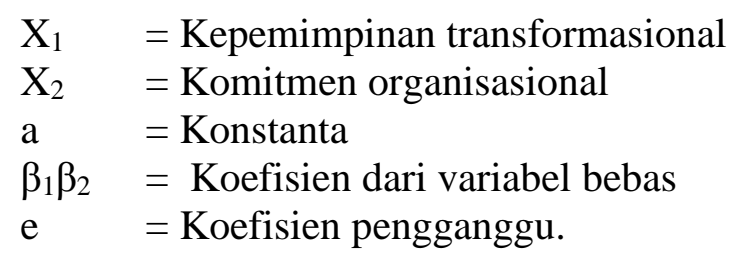

Uji F bertujuan untuk mengetahui kelayakan model regresi linear berganda sebagai alat analisis yang menguji pengaruh variabel independen terhadap variabel dependen secara bersama. Uji t digunakan untuk mengetahui apakah suatu variabel bebas secara individu berpengaruh terhadap variabel terikatnya.

\section{HASIL DAN PEMBAHASAN}

Suatu instrument dikatakan valid jika korelasi antara skor faktor dengan skor total bernilai positif dan nilainya lebih dari 0,30 ( $\mathrm{r}>0,3)$. Berikut Tabel uji validitas instrumen penelitian.

Tabel 2.

\section{Hasil Uji Validitas}

\begin{tabular}{cccc}
\hline Variabel & Indikator & Koefisien Korelasi & Keterangan \\
\hline Kepemimpinan & $\mathrm{X}_{1.1}$ & 0,595 & Valid \\
Transformasional $\left(\mathrm{X}_{1}\right)$ & $\mathrm{X}_{1.2}$ & 0,485 & Valid \\
& $\mathrm{X}_{1.3}$ & 0,620 & Valid \\
& $\mathrm{X}_{1.4}$ & 0,688 & Valid \\
Komitmen & $\mathrm{X}_{2.1}$ & 0,821 & Valid \\
Organisasional $\left(\mathrm{X}_{2}\right)$ & $\mathrm{X}_{2.2}$ & 0,701 & Valid \\
& $\mathrm{X}_{2.3}$ & 0,548 & Valid \\
Organizational & $\mathrm{Y}_{1}$ & 0,622 & Valid \\
Citizenship Behavior & $\mathrm{Y}_{2}$ & 0,648 & Valid \\
(Y) & $\mathrm{Y}_{3}$ & 0,694 & Valid \\
& $\mathrm{Y}_{4}$ & 0,552 & Valid \\
& $\mathrm{Y}_{5}$ & 0,658 & Valid \\
\hline
\end{tabular}

Sumber : data diolah, 2017

Hasil uji validitas pada tabel diatas menunjukkan bahwa seluruh variabel memiliki nilai koefisien korelasi dengan skor total seluruh item pernyataan lebih besar dari 0,30. Hal ini menunjukkan bahwa butir-butir pernyataan dalam 
instrument penelitian tersebut valid sehingga dapat digunakan untuk melakukan penelitian.

Suatu instrument dikatakan reliabel, jika instrument tersebut memiliki nilai Alpha Cronbach lebih dari 0,60. Adapun hasil dari uji reliabilitas dapat ditunjukkan pada tabel berikut:

Tabel 3.

\section{Uji Reliabilitas}

\begin{tabular}{clcc}
\hline No. & \multicolumn{1}{c}{ Variabel } & Cronbach's Alpha & Keterangan \\
\hline $\mathbf{1}$ & Kepemimpinan Transformasional $\left(\mathrm{X}_{1}\right)$ & 0,721 & Reliabel \\
$\mathbf{2}$ & Komitmen Organisasional $\left(\mathrm{X}_{2}\right)$ & 0,764 & Reliabel \\
$\mathbf{3}$ & Organizational Citizenship Behavior $(\mathrm{Y})$ & 0,749 & Reliabel \\
\hline Sumber $:$ data diolah, 2017
\end{tabular}

Hasil uji reliabilitas yang disajikan dalam Tabel menunjukkan bahwa seluruh instrumen penelitian memiliki koefisien Cronbach's Alpha lebih dari 0,60. Hal ini dapat dikatakan bahwa semua instrumen reliabel sehingga dapat digunakan untuk melakukan penelitian.

Tabel 4.

Hasil Analisis Regresi Linier Berganda

\begin{tabular}{|c|c|c|c|c|c|c|}
\hline \multirow{2}{*}{\multicolumn{2}{|c|}{ Model }} & \multicolumn{2}{|c|}{$\begin{array}{l}\text { Unstandardized } \\
\text { Coefficients }\end{array}$} & \multirow{2}{*}{$\begin{array}{c}\begin{array}{c}\text { Standardize } \\
\text { d } \\
\text { Coefficients }\end{array} \\
\text { Beta } \\
\end{array}$} & \multirow[t]{2}{*}{$\mathbf{T}$} & \multirow[t]{2}{*}{ Sig. } \\
\hline & & B & Std. Error & & & \\
\hline \multirow[t]{8}{*}{1} & (Constant) & .865 & 3.002 & & .288 & .775 \\
\hline & Kepemimpinan & .521 & 194 & .386 & 2.684 & .012 \\
\hline & Trasnformasional & & & & & \\
\hline & Komitmen Organisasional & .863 & .250 & 496 & 3.450 & .002 \\
\hline & $\mathbf{R}$ & & & & & 0,769 \\
\hline & R Square & & & & & $\mathbf{0 , 5 9 2}$ \\
\hline & F Statistik & & & & & 19,549 \\
\hline & Signifikansi & & & & & 0,000 \\
\hline
\end{tabular}

Berdasarkan hasil analisis regresi linier berganda seperti yang disajikan pada Tabel, maka persamaan strukturalnya adalah sebagai berikut :

$Y=\alpha+\beta_{1} X_{1}+\beta_{2} X_{2}+e$ 
$\mathrm{Y}=\alpha+0,521 \mathrm{X}_{1}+0,863 \mathrm{X}_{2}$

Nilai koefisien determinasi $\left(\mathrm{R}^{2}\right)$ 0,592 mempunyai arti bahwa sebesar 59,2\% variasi OCB dipengaruhi oleh variasi Kepemimpinan Transformasional, dan Komitmen Organisasional, sedangkan sisanya sebesar 40,8\% djelaskan oleh faktor lain yang tidak dimasukkan ke dalam model.

Uji asumsi klasik dilakukan dengan tujuan untuk memastikan hasil yang diperoleh memenuhi asumsi dasar di dalam analisis regresi. Hasil uji asumsi klasik yang dilakukan dalam penelitian ini adalah uji normalitas, uji multikoliniearitas, uji autokorelasi dan uji heteroskedastisitas. Uji normalitas bertujuan untuk mengetahui apakah residual dari model regresi yang dibuat berdistribusi normal atau tidak. Untuk menguji apakah data yang digunakan normal atau tidak dapat dilakukan dengan menggunakan uji Kolmogorov Sminarnov. Apabila koefisien Asymp. Sig. (2-tailed) lebih besar dari 0,05 maka data tersebut dikatakan berdistribusi normal. Nilai Kolmogorov Sminarnov (K-S) sebesar 0,594 sedangkan nilai Asymp. Sig. (2-tailed) sebesar 0,873. Hasil tersebut mengindikasikan bahwa model persamaan regresi tersebut berdistribusi normal karena nilai Asymp. Sig. (2-tailed) 0,873 lebih besar dari nilai alpha 0,05.

Uji multikolinearitas bertujuan untuk menguji apakah pada model regresi ditemukan adanya korelasi antar variabel bebas. Adanya multikolinearitas dapat dilihat dari nilai tolerance atau variance inflation factor (VIF). Jika nilai tolerance lebih dari $10 \%$ atau VIF Kurang dari 10, maka dikatakan tidak ada multikolinearitas. Berdasarkan Tabel dapat dilihat bahwa nilai tolerance dan VIF dari seluruh variable menunjukkan bahwa nilai tolerance untuk setiap variabel 
lebih besar dari $10 \%$ dan nilai VIF lebih kecil dari 10 yang berarti model persamaan regresi bebas dari multikolinearitas.

Uji heteroskedastisitas bertujuan untuk mengetahui apakah dalam model regresi terjadi ketidaksamaan varians dari residual satu pengamatan ke pengamatan lain yang dilakukan dengan uji Glejser. Jika tidak ada satu pun variabel bebas yang berpengaruh signifikan terhadap nilai absolute residual atau nilai signifikansinya di atas 0,05 maka tidak mengandung gejala heteroskedastisitas. nilai Sig. dari variabel Kepemimpinan Transformasional, dan Komitmen Organisasional, masing-masing sebesar 0,309 dan 0,660. Nilai tersebut lebih besar dari 0,05 yang berarti tidak terdapat pengaruh antara variabel bebas terhadap absolute residual. Dengan demikian, model yang dibuat tidak mengandung gejala heteroskedastisitas.

Uji keterandalan model atau uji kelayakan model atau yang lebih populer disebut sebagai uji F (ada juga yang menyebutnya sebagai uji simultan model) merupakan tahapan awal mengidentifikasi model regresi yang diestimasi layak atau tidak. Layak (andal) disini maksudnya adalah model yang diestimasi layak digunakan untuk menjelaskan pengaruh variabel-variabel bebas terhadap variabel terikat. Nama uji ini disebut sebagai uji F, karena mengikuti mengikuti distribusi F yang kriteria pengujiannya seperti One Way Anova. Hasil uji anova (UJI F) di atas, diperoleh nilai antar kelompok pembanding $=2$, nilai dalam kelompok penyebut $=29$, pada alfa $=0,05$ maka nilai $\mathrm{F}$ tabelnya adalah $\mathrm{F} 0,05(2,29)=3,33$. Sedang F hitung $=19,549$. Nilai Fhitung $>$ Ftabel, 19,549 > 3,33, dengan nilai sig. 0,000 < 0,05. Maka H0 ditolak pada taraf nyata 0,05 (H1 diterima). 
Made Satwika Dwi Cahyadi, Pengaruh Kepemimpinan Transform...

Kesimpulannya, pada kelompok yang diuji memiliki perbedaan yang nyata (signifikan) berarti bahwa Kepemimpinan Transformasional dan Komitmen Organisasional secara simultan berpengaruh signifikan terhadap OCB.

Hasil pengujian hipotesis variabel kepemimpinan transformasional terhadap OCB diperoleh Sig.t sebesar 0,012 dengan koefisien beta 0,521. Tingkat signifikansi $0,012<0,05$ mengindikasikan bahwa kepemimpinan transformasional berpengaruh positif dan signifikan terhadap OCB. Artinya apabila kepemimpinan transformasional meningkat, maka OCB juga akan mengalami peningkatan. Berdasarkan hal tersebut maka hipotesis komitmen organisasional berpengaruh positif terhadap OCB dapat diterima.

Pengujian hipotesis ini mengembangkan penelitian yang dilakukan oleh Hasil penelitian Amber Humphrey (2012) melakukan penelitian pada 128 karyawan swasta di Kansas menunjukan bahwa kepemimpinan transformasional berpengaruh positif terhadap OCB. Humphrey (2012) mengatakan bahwa hubungan positif ini disebabkan karena dipandangannya pemimpin sebagai panutan, adanya kepercayaan, motivasi, perhatian terhadap kebutuhan karyawan sehingga dengan demikian karyawan memiliki kecenderungan untuk melaksanakan perilaku ekstra peran (OCB). Penelitian yang dilakukan oleh Lian dan Tui (2012) menunjukan bahwa gaya kepemimpinan transformasional memiliki hubungan positif yang signifikan terhadap OCB bawahan.

Hasil penelitian Lee et al. (2013) membuktikan bahwa kepemimpinan transformasional memiliki pengaruh positif dan signifikan terhadap OCB. Hal ini ditunjukan dari semakin seringnya pemimpin mendorong karyawan untuk 
mencapai tujuan organisasi dan semakin banyak karyawan merasa percaya diri atas kemampuan mereka untuk melaksanakan tugas dan hal ini secara tidak langsung mempengaruhi karyawan untuk rela melakukan OCB. Penelitian Maptuhah Rahmi (2013) pada 125 guru tetap SMA Negeri di Kabupaten Lombok Timur mengungkapkan bahwa kepemimpinan transformasional berpengaruh positif dan signifikan terhadap OCB. Apabila intensitas penerapan kepemimpinan transformasional tinggi, maka tingkat OCB akan meningkat (Rahmi, 2013). Lamidi (2008) melakukan penelitian pada 42 dosen di Surakarta mengungkapkan bahwa kepemimpinan transformasional memiliki pengaruh positif terhadap OCB, dimana semakin tinggi persepsi yang dimiliki bawahan terhadap atasannya, maka OCB akan semakin tinggi.

Hasil penelitian ini mengindikasikan bahwa para pemimpin yang memiliki karisma dalam mememimpin, kaya akan ide dan inspirasi, memiliki keyakinan dalam setiap penggambilan keputusan, serta memiliki stimulasi intelektual yang baik dalam upaya mempengaruhi dan mengarahkan pengikutnya nantinya akan dapat menningkatkan prilaku kepemimpinan transformasional yang juga diharapkan dapat membantu meningkatkan prilaku OCB pada karyawan. Perilaku OCB yang meningkat ditandai dengan niat membantu rekan sekerja dengan sukarela, patuh terhadap peraturan perusahaan, tidak memberikan isu-isu yang dapat menjatuhkan karyawan lain, membatu meringankan masalah-masalah yang dihadapi sesama karyawan dan mendukung fungsi-fungsi organisasi secara professional. 
Made Satwika Dwi Cahyadi, Pengaruh Kepemimpinan Transform...

Hasil pengujian hipotesis variabel komitmen organosasional terhadap OCB diperoleh nilai Sig.t sebesar 0,002 dengan koefisien beta 0,863. Tingkat singnifikansi $0,002<0,05$ mengindikasikan bahwa komitmen organosasional berpengaruh positif dan signifikan terhadap OCB. Artinya apabila komitmen organosasional meningkat, maka OCB karyawan juga akan mengalami peningkatan. Berdasarkan hal tersebut maka hipotesis komitmen organisasional berpengaruh positif terhadap OCB dapat diterima.

Pengujian hipotesis ini mengembangkan penelitian yang dilakukan oleh Suparta, dkk (2013) menyatakan komitmen organisasional berpengaruh positif dan signifikan terhadap OCB, artinya setiap peningkatan komitmen organisasional akan berakibat pada peningkatan OCB. Penelitian yang dilaksanakan oleh Bakan et al. (2013) menemukan bahwa ada hubungan yang signifikan antara komitmen organisasional dan OCB di kalangan perempuan pekerja di sektor tekstil Kahramanmaras, Turki.

Hasil penelitian Merry (2013) yang menyatakan bahwa komitmen organisasional mempunyai pengaruh positif dan signifikan terhadap OCB karyawan di Rumah Sakit Bhayangkara trijata Denpasar. Penelitian yang dilaksanakan oleh Anshori (2013) menemukan bahwa adanya hubungan antara komitmen organisasional dengan OCB. Berdasarkan analisis koefisien korelasi regresi antara komitmen organisasional dengan OCB menunjukan adanya hubungan positif yang signifikan. Artinya semakin tinggi nilai komitmen organisasional seorang karyawan maka semakin tinggi pula nilai OCB karyawan 
tersebut. Rehan et al. (2013) mengungkapkan bahwa keseluruhan bentuk komitmen mempengaruhi OCB secara signifikan.

Hasil penelitian ini mengindikasikan bahwa para karyawan yang merasa bangga terhadap perusahaan, memiliki kekhawatiran akan resiko yang diterima jika meninggalkan organisasi dan percaya bahwa tidak etis jika karyawan meninggalkan organisasinya. Perilaku OCB yang meningkat ditandai dengan niat membantu rekan sekerja dengan sukarela, patuh terhadap peraturan perusahaan, tidak memberikan isu-isu yang dapat menjatuhkan karyawan lain, membatu meringankan masalah-masalah yang dihadapi sesama karyawan dan mendukung fungsi-fungsi organisasi secara profesional. Perilaku OCB para karyawan dapat ditingkatkan dengan cara meningkatkan intensitas penerapan komitmen organisasional bawahan.

\section{SIMPULAN DAN SARAN}

Berdasarkan hasil analisis penelitian dan hasil pembahasan diatas, maka dapat ditarik beberapa kesimpulan yaitu kepemimpinan trasformasional berpengaruh positif dan signifikan terhadap OCB pada karyawan Villa Kubu Manggala Seminyak. Pengaruh ini memiliki arti yaitu semakin tinggi tingkat kepemimpinan transformasional maka perilaku OCB pada karyawan akan semakin meningkat. Komitmen organisasional berpengaruh positif dan signifikan terhadap OCB pada karyawan Villa Kubu Manggala Seminyak. Pengaruh ini memiliki arti yaitu semakin tinggi tingkat komitmen organisasional maka perilaku OCB pada karyawan juga akan semakin meningkat. 
Made Satwika Dwi Cahyadi, Pengaruh Kepemimpinan Transform...

Berdasarkan dan kesimpulan di atas maka beberapa saran yang dapat dipergunakan sebagai bahan pertimbangan dalam menentukan kebijakan bagi Villa Kubu Manggala Seminyak di masa mendatang terutama yang berkaitan dengan kepemimpinan transformasional, komitmen organisasional, dan OCB, antara lain untuk dapat meningkatkan prilaku OCB pada karyawan, maka sebaiknya pemimpin meningkatkan keyakinan yang merupakan indikator dari kepemimpinan transformasional dengan cara memberikan kesempatan dan kepercayaan kepada karyawan untuk dapat menyumbangkan ide dan masukan bagi perusahaan yang tujuannya adalah untuk membantu tercapainya tujuan perusahaan. Dari faktor komitmen organisasional juga masih perlu ditingkatkan dengan memberikan kesempatan pada karyawan untuk dapat terlibat langsung dalam setiap kegiatan organisasi agar dapat meningkatkan rasa bangga dan nantinya diharapkan dapat meningkatkan perilaku OCB pada karyawan Villa Kubu Manggala Seminyak.

\section{REFERENSI}

Abu-Tineh, A. M., Khasawneh, S. A., and Al-Omari, A. A. (2008). Kouzes and Posner's transformational leadership model in practice: The case of Jordanian schools. Leadership \& Organization Development Journal, 29(1), pp: $648-660$.

Andriani, Gita. 2012. Organizational Citizenship Behavior dan Kepuasan Kerja pada Karyawan. Fakultas Psikologi Universitas 17 Agustus 1945 Surabaya. Jurnal Penelitian Psikologi, 03(1), pp: 341-345.

Anshori, M. Isa. 2013. Relasi Komitmen Organisasi dan Kepuasan Kerja terhadap Organizational Citizenship Behavior (Studi Kasus di Poltekes Surabaya). 4(1), pp: 42-50.

Aydogdu, Sinem dan Baris Asikgil. 2011. An Empirical Study of the Relationship Among Job Satisfaction, Organizational Commitment and Turnover 
Intention. International Review of Management and Marketing, 1(3), pp: 43-53.

Babcock-Roberson, M.E. dan Strickland, O.J. 2010, “The Relationship Between Charismatic Leadership, Work Engagement, and Organizational Citizenship Behaviors". Journal of Psychology. 144(3), pp: 313-326.

Bakan, Ismail, Tuba Buyukbese, Burcu Frsahan and Ilker Kefe. 2013. The Effect of Organizational Commitment and Women Employee Organizational Citizenship Behavior. Indian Journal of Applied Research, 3(2). pp: 202204

Bass, Bernard M. dan Ronald E. Riggio. 2006. Transformational Leadership Second Edition. Mahwah, New Jersey London: Lawrence Erlbaum Associates, Publishers.

Cho, J.,and Dansereau. 2010. Are Transformational Leaders Fair?. The Leadership Quarterly. 21(3), pp: 209-421.

Davoudi, Seyed. 2010. Organizational commitment and Extra Role Bahavior: A Survey in Iran's Insurance Industry. Journal of Business System, Governance and Ethics, 7(1), pp: 66-75.

Fung, N. S., Ahmad, A., dan Omar, Z. 2012. Work-family Enrichment: It's Mediating Role In the Relationships between Dispositional Factors and Job Satisfaction. International journal of Academic Research in Business and Social Sciences. 2(11), pp: 11-88.

Hasibuan, Malayu S.P.( 2008 :170). Manajemen Sumber Daya Manusia. Edisi Revisi. Jakarta: Bumi Aksara.

Hee Lee, Ung, Hye Kyoung Kim and Young Hyung Kim. 2013. Determinants of Organizational Citizenship Behavior and Its Outcomes. International Journal Global Business \& Management. 5(1). Pp: 54-65.

Humphrey, Amber. 2012. Transformational Leadership and Organizational Citizenship Behavior: A Review of Literature. Journal of Management \& Public Policy. 1(2), pp: 101-113.

Ismail, A., Mohamed, H., Sulaiman, A.Z., Mohamed, M.M., and Yusuf, M.H. 2011. An Empirical Study of the Relationship between Transformational Leadership, Empowerment and Organizational Commitment, Business and Economic Research Journal, 2(1), pp. 89-107

Karim, Faizal, Rehman, Omar. 2012. Impact of Job Satisfaction, Perceived on Organizational Justice and Employee Empowerment on Organizational Commitment in Semi-Government Organization of Pakistan. Journal of Business Studies Quarterly, 3(4), pp: 92-104. 
Konovsky, M.A and Pugh. S.D. 1994. Citizenship Behavior and Social Exchange. Academy of Management Journal, 37(3), pp :54-58

Kumar, K., Bakhshi, A., and Rani, E. 2009. Linking the Big Five Personality Domains to Organizational Citizenship Behavior, International Journal of Psychological Studies, 1(2), pp. 73-81.

Lamidi. 2008. Pengaruh Kepemimpinan Transformasional terhadap Organizational Citizenship Behavior. Jurnal Ekonomi dan Kewirausahaan, 8(1), pp: $25-37$

Latan, Hengky. 2012. Structural Equation Modeling: Konsep dan Aplikasi Menggunakan Program LISREL 8.80. Bandung: Penerbit Alfabeta

Lian, L.K., and Tui, L.G. 2012. Leadership Style and Organizational Citizenship Behavior: The Mediating Effect of Subordinates' Competence and Downward Influence Tactic, Journal of Applied Business and Economics, 13 (2), pp: 59-96.

Liden, R.C. Wayne, S.J., Kraimer, M.L., \& Sparrowe. (2003). The dual commitments of contingent workers: An examination of contingents' commitment to the agency and the organization. Journal of Organizational Behavior, 24(3), pp : 609-625.

Luthans, F. 2006. Perilaku Organisasi, Edisi sepuluh, Yogyakarta: penerbeti Andi.

Mayer, Jhon P. and Allen, Natalie J. 1991. A Three-Component Conzeptualization of Organizational Commitment. Human Resource Management Review. 1(1), pp: 61-89.

Merry Ristiana, M. 2013. Pengaruh Komitmen Organisasi Dan Kepuasan kerja Terhadap Organizational Citizenship Behavior (OCB) Dan Kinerja Karyawan Rumah Sakit Bhayangkara Trijata Denpasar.Jurnal Ilmu Ekonomi \& Manajemen, 9(1), pp. 56-70.

Mohamed, Sheik., Anisa. 2012. Relationship between Organizational Commitment and Organizational Citizenship Behavior. The IUP Journal of Organizational Behavior, 9(3), pp: 122-143.

Mudiartha Utama I Wayan, I Komang Ardana, A.A. Sagung Kartika Dewi, A.A.A. Sriathi. 2015. Pengaruh Keamanan Kerja Pada Turnover Intention dengan Kepuasaan Kerja Sebagai Variabel Pemediasi. Jurnal Manajemen Strategi Bisnis dan Kewirausahaan. 9(1), pp: 42-56.

Ngadiman., Anis Eliyana, and Dwi Ratmawati. 2013. Influence of Transformational Leadership and Organizational Climate to the Work Satisfaction, Organizational Commitment and Organizational Citizenship 
Behavior on the Education Personnel of Sebelas Maret University, Surakarta. European Journal of Business and Management, 5(10), pp: 97114.

Organ, D.W., Podsakoff, P.M., and MacKenzie, S.B. 2006. Organizational Citizenship Behavior: Its Nature, Antecedents, and Consequences, SAGEPublications.

Rehan, Muhammad., Talat Islam. 2013. Relationship Between Organizational Commitment and Citizenship Behavior. World Journal of Management and Behavior Studies, 1(1), pp: 24-32.

Rorimpandey, Lidya. 2013. Gaya Kepemimpinan Transpormasional, Transaksional, Situasional, Pelayanan dan Autentik Terhadap Kinerja Pegawai Keluraha Di Kecamatan Bunaken Kota Manado. Jurnal EMBA. 1(4): pp: 89-90

Saeed, Asmir and Shahbaz Ahmad. 2012. Perceived Transformational Leadership Style and Organizational Citizenship Behavior: A Case Study of Administrative Staff of University of the Punjab. European Journal of Business and Management. 4(21): pp: 150-158.

Saeed, R., Hashmi, A., Lodhi, R. N., \& Rehman, I. 2013. The Effect of Transformational Leadership on Organizational Commitment with a Mediating Effect of Psychological Empowerment. Journal of Basic and Applied Scientific Research. 3(6), pp: 28-36

Saptoani, Avianti. 2011. Organizational Citizenship Behavior Tenaga Pendidik. Bayu Media Publishing: Malang

Simamora,Hendry. 2004. Manajemen Sumber Daya Manusia. Edisi 1 Yogyakarta.

Sugiyono. 2013. Metode Penelitian Bisnis. Bandung: Alfabeta.

Suparta, Putu Jannanda, Wayan Gede Supartha dan Wayan Mudiartha Utama. 2013. Pengaruh Moral Karyawan dan Komitmen Organisasi Terhadap Organizational Citizenship Behavior dan Kinerja Individual Karyawan (Studi Kasus di Rama Beach Resort \& Villas). E-journal Ekonomi dan Bisnis Universitas Udayana. 2(11),pp: 85-92

Surbakti. 2013. Analisis Pengaruh Kepemimpinan Transformasional dan Motivasi terhadap Kinerja Karyawan: Studi pada PT. Kereta Api Indonesia Daop IV Semarang. Journal Fakultas Ekonomi Universitas Diponegoro Semarang, 1 (1), pp: 55-67.

Shweta Jha., Srirang Jha. 2010. Determinants of Organizational Citizenship Behavior: A Review of Literature. Journal of Management \& Public Policy., 1(2), pp: 101-113 
Made Satwika Dwi Cahyadi, Pengaruh Kepemimpinan Transform...

Thoha, Mitfah. 2010. Perilaku Organisasi. Konsep Dasar dan Aplikasinya. Jakarta : PT. Raja Grafindo Persada.

Waspodo, Agung AWS dan Lussy Minadaniati. 2012. Pengaruh Kepuasan Kerja dan Iklim Organisasi Terhadap Organizational Citizenship Behavior Karyawan PT. Trubus Swadaya. Journal Riset Manajemen Sains Indonesia (JRMSI), 3(1), pp: 1-16.

Wibowo, Edi. Dan Wiwik Susilowati. 2010. Pengaruh Kepemimpinan, Organizational Citizenship Behavior, dan komitmen organisasional terhadap kepuasan kerja pegawai. Jurnal Ekonomi dan Kewirausahaan, 10 (1), pp: 66-73.

Wuradji. 2008. The Educational Leadership (Kepemimpinan Transformasional). Yogyakarta : Gama Media.

Zahari, I.B., and Subarghi, A.M.A. 2012. The Effect of Organizational Culture and The Relationship Between Transformational Leadership and Job in Sector of Libya. International Business Research. 5(9), pp:89-97. 